\title{
DIREITOS HUMANOS E PESSOAS COM DEFICIÊNCIA: O ÂMBITO PRIMÁRIO DA REIVINDICAÇÃO CONCRETIZADORA DA CONVENÇÃO SOBRE OS DIREITOS DAS PESSOAS COM DEFICIÊNCIA E OS DESAFIOS NA REALIDADE BRASILEIRA
}

\section{HUMAN RIGHTS AND PEOPLE WITH DISABILITIES: THE PRIMARY SPHERE OF THE CLAIM THAT EFFECTIVES THE CONVENTION ON THE RIGHTS OF PERSONS WITH DISABILITIES AND THE CHALLENGES IN THE BRAZILIAN REALITY}

\section{VICENTE ELÍSIO DE OLIVEIRA NETO}

Membro do Ministério Público do Estado do Rio Grande do Norte. Doutorando do Programa de Pós-graduação em Ciências Jurídicas da Universidade Federal da Paraíba. Bolsista CAPES (Doutorado Sanduíche) na Universidade Eduardo Mondlane-Moçambique, no âmbito do Projeto CAPES-AULP no 88887.159754/201400. Mestre em Direito Constitucional pela Universidade Federal do Rio Grande do Norte. Especialista em Direito de Família e Sucessões pelas Faculdades Integradas de Jacarepaguá do Rio de Janeiro. Graduado em Direito pela Universidade Federal do Rio Grande do Norte. E-mail: vicenteelisio@yahoo.com.br

\section{RESUMO}

O artigo tem por objeto a questão jurídico-política, emergente da dualidade sistêmica internacional e local, indagando quanto ao âmbito mais adequado e potencialmente eficaz para o equacionamento das reivindicações concretizadoras dos direitos humanos/fundamentais titularizados pelo contingente social com deficiência discriminado e excluído das diversas esferas do meio social, submetendo à verificação hipótese que sinaliza a primazia do sistema de proteção jurisdicional local supondo o caráter limitado, subsidiário, suplementar e não acidentalmente débil 
do sistema internacional de garantia dos direitos humanos. Contrapõe-se o projeto teórico do Estado de Direito Global comprometido com os direitos humanos, a democracia e a paz proposto por Bobbio à crítica da jurisprudência liberal dos direitos humanos estabelecida por Douzinas, destacando o imperativo emancipatório que estrutura e articula a normatividade da Convenção de Nova lorque (ONU, 2006) e os desafios da realidade brasileira.

PALAVRAS-CHAVE: Direitos Humanos; Pessoa com deficiência; Convenção sobre os Direitos das Pessoas com deficiência; Sistema de proteção internacional; Sistema de proteção local.

\section{ABSTRACT}

The papper focuses on the political-judicial question that emerges from the international and local systemic duality, making inquiries regarding the most appropriate and potentially effective scope for the settlement of claims that make concrete the human/fundamental rights, carried out by the social contingent with disabilities, that suffer discrimination and is excluded from the various spheres of society, submitting to the verification the hypothesis that signals the primacy of the local judicial protection system, assuming the limited, subsidiary, supplementary and not accidentally weak character of the international human rights guarantee system. Therefore, opposes the Global Rule of Law theoretical project committed to human rights, the democracy and peace proposed by Bobbio to the critique of liberal human rights law established by Douzinas, highlighting the emancipatory imperative that structure and articulates the normativity of the New York Convention (UN, 2006) and the challenges of the Brazilian reality.

KEYWORDS: Human Rights; People with disabilities; Convention on the rights of persons with disabilities; International protection system; Local protection system. 


\section{INTRODUÇÃO}

A incorporação das questões afetas às pessoas com deficiência, enquanto contingente humano historicamente discriminado, secundarizado e oprimido nas dimensões normativa, teórica e prática dos direitos humanos dá ensejo à eclosão e ao reconhecimento de problemas de alto relevo resultantes do entrelaçamento temático, dentre os quais se distingue o aparente paradoxo de um sistema jurídico de proteção que quanto mais expande seu escudo de salvaguardas mais se agigantam, sob os prismas quantitativo e qualitativo, as correspondentes e indesejadas violações, impondo-se a busca de soluções para o impasse.

Sob o influxo de tal contexto, o presente artigo tem por objeto a dualidade sistêmica internacional e local, investigando qual o âmbito mais apropriado e potente para o manejo e o equacionamento das pretensões concretizadoras das cláusulas emancipadoras da Convenção sobre os Direitos das Pessoas com Deficiência CDPD à luz dos desafios emergentes na realidade brasileira.

A hipótese que se submete ao fogo cruzado da contenda jurídico-política sinaliza a primazia do sistema de proteção jurisdicional local supondo o caráter limitado, subsidiário, suplementar e não acidentalmente débil do sistema internacional de garantia dos direitos humanos.

Na primeira parte, ter-se-á em consideração o modelo de Estado de Direito Planetário, de conformação axiológica e procedimental nitidamente ocidental e de viés kantiano. O arquétipo caracterizado pela proteção dos direitos do homem, submissão aos parâmetros democráticos e por seu comprometimento teleológico com a paz, seria progressivamente instituído por meio do aperfeiçoamento sistêmico, segundo Bobbio (2004). Tendo por contraponto a contestação à jurisprudência liberal esgrimida por Douzinas (2009), buscar-se-á desvelar no percurso o comprometimento axiológico/ideológico de algumas premissas aparentemente neutras do discurso jurídico tradicional e muito influente, assim como demonstrar a primazia do contexto local para o equacionamento da demanda direcionada à materialização dos direitos humanos.

$\mathrm{Na}$ parte subsequente, cuidar-se-á da compreensão dos processos que deram ensejo à confecção e à absorção da Convenção de New York (ONU, 2006) 
pelo sistema das nações unidas de proteção aos direitos humanos e pelo ordenamento local. Pretende-se destacar particularmente as abordagens relativas ao fenômeno da deficiência, as implicações sociais e jurídicas que emanam do texto convencional e suas diretrizes estruturadas em torno do propósito de inclusão da parcela humana com deficiência, por meio da efetiva garantia dos seus direitos.

Em arremate, pretendendo evidenciar a magnitude dos desafios postos no cenário nacional, a pesquisa se dedica ao esquadrinhamento da fundamentação do julgamento pelo Superior Tribunal de Justiça-STJ de Recurso Especial em Ação Civil Pública tendo por objeto direitos e interesses da coletividade com deficiência visual no contexto de relação de natureza contratual com instituição financeira, no qual o Tribunal inaugurou o emprego das cláusulas convencionais na justificação do provimento jurisdicional versando sobre questão transindividual, de natureza cível, encerrando-se a empresa investigatória com a exposição das conclusões.

\section{UM NOVO "FIM" PARA "A ERA DOS DIREITOS": A PRIMAZIA DO CONTEXTO LOCAL PARA O EQUANCIONAMENTO DA DEMANDA DIRECIONADA À MATERIALIZAÇÃO DOS DIREITOS HUMANOS}

O desavisado que acidentalmente ultrapassar as fronteiras que delimitam, sem muita precisão, os campos dos estudos dos direitos humanos poderá defrontarse com as perturbadoras e confusas sensações que, em intensidade e amplitude, muito se assemelham àqueles que supostamente acometiam os prisioneiros da caverna e do labirinto, legados da filosofia e da mitologia helênicas.

Postulados e teorizações filosóficas, sociológicas e jurídicas, ora se entrelaçam, ora se afastam na busca de respostas a questões aporéticas atinentes ao fundamento ${ }^{1}$, à natureza, ao caráter universal ou particular, à viabilidade total ou

\footnotetext{
${ }^{1}$ Sob a perspectiva da dogmática jurídica, o problema é assim posto por Enoque Feitosa (2013, p.79): "[...] definir o status ontológico dos direitos e de saber se eles são fundamentados internamente por cada ordem jurídica ou se há um fundamento externo e supra-jurídico para os mesmos. Essa questão não é de somenos valor: ela divide a filosofia do direito, grosso modo, entre os jusnaturalistas - que teimam em encontrar um fundamento - imanente ou transcendente, não importa - anterior, superior ao direito e sempre desvinculado de sua base social, e os juspositivistas, pela qual o fundamento do direito é autoreferente e indiferente àquelas questões que Kelsen afirmaria como próprias da sociologia, da política, mas nunca do direito."
} 
parcial do programa antinômico (FREITAS, 2012, p. 226 e ss), e mesmo quanto à propriedade, sob o prisma linguístico, da expressão "direitos humanos", dentre tantas outras indagações "difíceis" e constatações paradoxais.

No entanto, interessa aos fins do presente artigo a consideração neste tópico da questão referente ao âmbito mais adequado e potencialmente mais promissor, sob o ângulo jurídico, para a interposição das reivindicações concretizadoras dos direitos humanos: o internacional (global ou regional) ou o local (nacional)?

Diga-se de imediato, que a indagação pressupõe necessariamente a filiação do estudo às correntes que sustentam a possibilidade de efetiva implementação dos direitos humanos, especialmente daqueles que consubstanciam o sistema especial de proteção dos direito das pessoas com deficiência, instituído pela Organização das Nações Unidas - ONU em 2006, por meio da Convenção sobre os Direitos das Pessoas com Deficiência - CDPD.

Assente-se igualmente desde já que o questionamento somente se reveste de atualidade e importância para os que ainda resistem à ideológica inferência da inevitabilidade da globalização neoliberal que implica inelutavelmente em supressão de direitos e incremento da exclusão social, tanto no Sul como também no Norte. Não se olvide que a ressurreição do pensamento liberal clássico investe contra as conquistas do welfare state - que sequer chegou a se consolidar no contexto latinoamericano - decorrendo do seu desmonte a contração de direitos e do próprio conceito universal de homem (LOSURDO, s.d., p. 23 e ss).

Recorde-se ainda que a igualdade de direitos ${ }^{2}$, mesmo a estritamente formal, nunca foi compreendida e justificada teoricamente ou encampada na prática

\footnotetext{
2 Sustenta Dalmo de Abreu Dallari (2011) que a igualdade jurídico-formal de todos os seres humanos em dignidade e direitos é conquista recente da humanidade, vez que somente foi estabelecida por meio da Declaração Universal dos Direitos Humanos - DUDH (ONU, 1948). Diversamente da opinião ainda predominante em muitos círculos, os movimentos revolucionários deflagrados no século XVIII, nas colônias inglesas da América do Norte e na França não encartaram a igualdade dentre os direitos constitutivos da nova ordem jurídica liberal instituída pela burguesia vitoriosa, questão de fundo que pode ter permanecido oculta em razão da ofuscante e perene propagação do inspirador e radioso lema francês da liberdade, igualdade e fraternidade. Ademais disso, evidencia o autor, com arrimo em dados histórica e sociologicamente confirmados, que a legislação de coloração liberal instituiu discriminações e desigualdades econômicas (voto censitário), de gênero (negação de direitos às mulheres), de raça (escravidão negra), dentre outras.
} 
pelos amantes incondicionais e exclusivos da liberdade egocêntrica: os prosélitos do pensamento liberal clássico.

Em obra clássica intitulada "A Era dos Direitos", sempre referenciada e muito influente na literatura nacional e internacional dedicada à temática dos direitos humanos, assentou Noberto Bobbio que o problema da fundamentação dos direitos do homem, com a positivação universal levada a efeito pela Declaração Universal dos Direitos Humanos-DUDH, em 1948, deveria ceder espaço para a questão relativa à proteção efetiva de tais direitos (BOBBIO, 2004, p. 22-23; 25-26; 37-38; 44; 76-77).

$\mathrm{Na}$ introdução da obra explicita Bobbio (2004, p. 01) a influência kantiana ${ }^{3}$ que anima sua construção teórica alicerçada no trilema direitos humanos/ democracia/ paz enquanto fundamentos do projeto de cidadania global em um estado de direito planetário.

Desde a ilusão jusnaturalista do estado de natureza, ficção doutrinária empregada para justificar supostos direitos naturais inalienáveis e imprescritíveis dos indivíduos, anteriores à comunidade política e, em consequência, oponíveis ao Leviatã, até a contemporaneidade, os direitos do homem estavam enredados em um processo histórico de gradativa expansão em um movimento dinâmico simultaneamente impulsionado pelas transformações do meio social e por uma correlata tendência ao progresso moral da humanidade.

Rejeitando o fundamento jusnaturalista dos direitos naturais, identifica Bobbio (2004, p. 58) quatro etapas do processo de afirmação e reconhecimento dos direitos do homem historicamente deflagrado a partir das revoluções burguesas vitoriosas do século XVIII e suas correspondentes declarações de direitos, a saber: positivação, generalização, internacionalização e especificação.

\footnotetext{
${ }^{3}$ Em obra clássica publicada na Alemanha em 1795, traduzida para a língua portuguesa sob o título "À paz perpétua", Immanuel Kant (1724-1804) esboça "um projeto filosófico" (KANT, 2016, p. 13) voltado à superação do estado de natureza - estado de guerra permanente, deflagrado ou latente no qual se encontravam enredados os Estados nacionais por meio de um pacto tendo por fim último a instituição das condições necessárias ao perene estado de paz entre os Estados. Conforme o filósofo de Königsberg, a realização da obra por ele idealizada envolveria: a) o reconhecimento da liberdade e da igualdade jurídicas como direitos inatos e imprescritíveis da humanidade, nos âmbitos nacional e internacional (KANT, 2016, pp 24, 25, 29, 72, 75 e 83); b) a constituição de uma Federação de Estados (KANT, 2016, pp 24, 31, 34, 35, 36, 37, 72, 79 e 82); c) em corolário, a instituição de um direito internacional cosmopolita preocupado com a solução pacífica das controvérsias entre os Estados (KANT, 2016, pp 23, 31, 35, 36, 37, 41 e 82).
} 
Não é difícil inferir que na base da identificação de tais fases encontra-se a teoria geracional (BOBBIO, 2004, p. 32) que sustenta a tendência perene de uma multiplicação gradativa de direitos. As atenções do autor voltam-se especialmente às etapas da internacionalização e da especificação.

$\mathrm{Na}$ fase da internacionalização, inaugurada pela Declaração Universal dos Direitos Humanos - DUDH (ONU, 1948), institui-se a sociedade de estados e indivíduos livres e iguais (BOBBIO, 2004, p. 27), decreta-se o fim da dicotomia direitos do homem/ direitos do cidadão (BOBBIO, 2004, p. 29-30) por meio da conversão universal em direitos positivos dos direitos do homem (BOBBIO, 2004, p. 31), nascendo assim o cidadão global titular de direitos positivos universais (BOBBIO, 2004, p. 30), sob as luzes ofuscantes oriundas da constelação axiológica universal, representando o documento, agora nas palavras de Bobbio (2004, p. 27), o fundamento histórico do consenso axiológico internacional.

Infere-se que a fase de internacionalização se completa com a edição dos Pactos Internacionais sobre os Direitos Civis, Políticos, Econômicos, Sociais e Culturais de 1966, assim como de outros documentos internacionais endereçados à instituição de uma proteção geral à humanidade, ao mesmo tempo em que no seu curso Bobbio capta a eclosão de uma nova tendência: a especificação.

A nova e contemporânea etapa, emergente das entranhas da fase anterior, diferencia-se sob o ângulo teleológico, pela pretensão de instituir no contexto mundial uma proteção jurídica especial a categorias ou grupos humanos vulneráveis (crianças, mulheres, pessoas com deficiência e idosos, dentre outros), em face da manifesta insuficiência da proteção jurídica geral abstratamente conferida a todos e, por isso mesmo, desatenta à diversidade própria do gênero humano e das implicações sociais e culturais de tais diferenças.

Em tal contexto, a constatação empírica da permanência e mesmo do incremento e da diversificação das violações dos direitos contrapõe-se ao processo de multiplicação gradativa dos direitos humanos. Tal paradoxo finda por atrair as atenções para o tema da efetiva implementação do catálogo alargado dos direitos do homem, impondo-se indagações particularmente referentes às causas das violações e às medidas para superá-las, questões de ordem jurídico-política, de natureza substancial e, ainda, de ordem objetiva, sendo essas últimas mais estreitamente 
ligadas à materialização dos direitos sociais, segundo Noberto Bobbio (2004, p. 19 e ss; 37 e ss; 76).

Sob o ângulo jurídico-político, assevera o autor que a tutela jurídica dos direitos humanos viabilizada pelo sistema internacional é mais fraca do que a proteção desses direitos instituída nos ordenamentos jurídicos nacionais vinculados ao modelo do rule of law. Assim, a debilidade do sistema internacional de proteção cresce em importância com relação aos Estados que não adotaram o figurino do "Estado de Direito" e que, de regra seriam os principais violadores dos direitos humanos.

A partir de tal pressuposição, propõe Bobbio (2004, p. 40 e 76) o aprimoramento do sistema internacional de garantia dos direitos do homem por meio do aumento do caráter representativo dos organismos internacionais e do estabelecimento de duas condições necessárias para o seu fortalecimento: a) que o reconhecimento e a proteção dos direitos humanos sejam requisitos para o ingresso e a permanência de um Estado na comunidade internacional; b) a instituição de um poder comum dotado de força bastante para prevenir ou reprimir as violações de direitos humanos por meio do manejo de uma tutela jurisdicional internacional.

A efetiva garantia dos direitos humanos também esbarra em óbices de natureza substancial, relacionados ao conteúdo e à inviabilidade de uma hierarquização apriorística e objetiva para os casos rotineiros de confrontos fáticos entre direitos que não são absolutos nem constituem uma categoria homogênea.

De acordo com Bobbio (2004, p. 19 e ss; 40 e ss), somente seriam absolutos os direitos fundamentais que não se coloquem em situação de concorrência com outros direitos também qualificados como fundamentais. Absolutos seriam apenas 0 direito a não ser escravizado e o direito de não ser torturado. Assim, via de regra, os direitos humanos são relativos por concorrerem entre si e, em face de tal circunstância, não podem ser simultaneamente tutelados em determinado contexto fático, de modo que se impõe a delimitação da extensão de cada direito fundamental tendo sempre em conta que a delimitação/restrição seria, ela própria, relativa por derivar de escolhas axiologicamente comprometidas.

Ainda sobre a problematização substancial, assenta o pensador italiano que a expressão "direitos do homem" insinua uma homogeneidade inexistente ao mesmo 
tempo em que oculta relações antinômicas entre os direitos de liberdade e os direitos sociais agrupados na categoria, não obstante incompatíveis entre si, vez que a proteção de uns impede total ou parcialmente a garantia de outros, asseverando o autor ser fantasiosa reivindicação de uma sociedade simultaneamente orientada pelos parâmetros de liberdade e justiça ${ }^{4}$.

Esse antagonismo axiológico anima as pelejas teóricas e políticas travadas entre os que se filiam às concepções de mundo liberal e socialista na guerra sem trégua e sem quartel pela prevalência da liberdade ou da igualdade material, respectivamente. Assim, conforme sustenta o autor, a aproximação entre os valores inconciliáveis promovida no âmbito da normatividade internacional foi apenas uma síntese provisória, um compromisso historicamente instituído e, exatamente por isso, sujeito a modificações no curso da história.

Por fim, a efetiva implementação dos direitos humanos se depara com dificuldades de caráter objetivo relativas à concreta inversão de recursos supostamente insuficientes, precipuamente nos países em desenvolvimento, imprescindíveis à materialização dos direitos prestacionais. Nessa linha de raciocínio, "[...] a efetivação de uma maior proteção dos direitos do homem está ligada ao desenvolvimento global da civilização humana [...]" direcionado à superação dos graves problemas representados pelo risco de uma guerra exterminadora e pela miséria que se abate sobre expressivo contingente da população mundial (BOBBIO, 2004, p. 44).

Tendo em vista o percurso previamente esboçado para o desenvolvimento do presente artigo, interessa especificamente apreciar em detalhes a questão jurídico-política apontada pelo filósofo e jurista italiano como um obstáculo a ser afastado para permitir a maximização da efetivação dos direitos humanos.

Inicialmente, diga-se que não se encontra lastro empírico no cenário mundial para assentar que quantitativa ou qualitativamente as violações de direitos humanos seriam provenientes da ação ou omissão de Estados institucionalmente divorciados do arcabouço formal próprio da modelagem reconhecida como Estado de Direito.

\footnotetext{
4 "As sociedades reais, que temos diante de nós, são mais livres na medida em que menos justas e mais justas na medida em que menos livres. Esclareço dizendo que chamo de 'liberdades' os direitos que são garantidos quando o Estado não intervém; e de 'poderes' os direitos que exigem uma intervenção do Estado para sua efetivação. Pois bem, liberdades e poderes, com frequência, não são - como se crê - complementares, mas incompatíveis". (BOBBIO, 2004, p. 42)
} 
Ademais, não demanda qualquer esforço de grande monta o empreendimento voltado a elencar os casos de graves violações de direitos humanos que repercutiram internacionalmente após o encerramento do segundo conflito bélico mundial para neles identificar a participação direta, aberta ou sorrateira, ou a omissão conivente daqueles Estados que, permanentemente, ocupam os cargos mais importantes da Organização das Nações Unidas - ONU, assim como de muitos outros Estados coadjuvantes que integram a associação e ocupam postos nos seus órgãos e agências.

Na obra "O fim dos Direitos Humanos", Costas Douzinas (2009) dedica atenção ao tema da proteção internacional dos direitos humanos enquanto questão que se insere no contexto de uma crítica à jurisprudência liberal dos direitos humanos (Douzinas, 2009, p. 21). Segundo o jusfilósofo grego, os direitos humanos ocupam espaço privilegiado na cultura global pós-moderna como sobreviventes incólumes das disputas ideológicas que marcaram a modernidade, como ideologia triunfante após o fim da história (Douzinas, 2009, p. 19 e ss).

Sem arrodeios e com alguma acidez, assenta Douzinas (2009, p. 20) que vislumbrar no curso do século XX a era dos direitos humanos é, ao menos, um paradoxo pois em tal quadra histórica têm-se o registro de massacres, genocídios, do holocausto, assim como a ampliação das distâncias entre pobres e ricos nas sociedades do Ocidente e entre os países do Norte e os do Sul, fatos evidenciadores de violações gravíssimas e sem precedentes de igual magnitude na história, perpetradas sem nenhuma consideração ou respeito à "Era dos direitos", inequívoca cisão de todas as conexões necessárias que articulam teoria e prática.

Douzinas (2009, p. 126 e ss) questiona a legitimidade do legislador internacional por ter se investido da condição de representante sem a necessária outorga de representação por parte da humanidade supostamente representada, evidenciado assim um vício formal ab initio que macula a empresa da universalização jurídica dos direitos humanos levada a cabo logo em seguida ao encerramento da Segunda Guerra Mundial. Sob o ângulo político, destaca o autor que a DUDH foi urdida com o propósito de legitimar a nova ordem internacional instituída pelos Estados vitoriosos no conflito mundial e que, em desdobramento, cada Estado restou (auto)legitimado. 
Assim como Bobbio (2004), Douzinas (2009, p. 129 e ss) identifica fragilidades e inadequações do sistema de proteção internacional dos direitos humanos. Todavia, diferentemente do jurista italiano, não aposta na possibilidade de aperfeiçoamento sistêmico visando incrementar a efetiva garantia dos direitos por meio de um Direito Internacional que confere à soberania do Estado o status de princípio fundamental. Assim, a precariedade dos mecanismos internacionais de direitos humanos não é acidental mas sim proposital: visa em geral preservar intacto o escudo da soberania do Estado violador ${ }^{5}$ (Douzinas, 2009, p.131).

Discorre Douzinas (2009, p. 134 e ss) sobre a hipocrisia e o cinismo dos Estados na comunidade internacional, na medida em que combinam práticas violadoras com forte retórica protetora dos direitos humanos contra os seus adversários, tradicionais ou ocasionais, não sendo incomum acusações recíprocas de afronta ao mínimo ético irredutível que mascaram interesses políticos e/ou econômicos de baixíssima estatura, inferência que supõe a possibilidade de uma política externa pautada em uma inexistente moralidade internacional e transcultural.

De igual modo, o "[...] tratamento dispensado a refugiados e outras populações que fogem de desastres naturais ou causados pelo homem. [...]" põe em xeque a normatividade universalizadora dos direitos humanos (Douzinas, 2009, p. 153), desafia a cidadania planetária proclamada em 1948. Entretanto, o que interessa aqui e agora é assentar a tese que Douzinas (2009, p. 129) já havia mencionado e passa a desenvolver: os direitos humanos são predominantemente violados ou protegidos no âmbito local.

Note-se que Douzinas (2009) mais uma vez se aproxima de Bobbio (2004) ambos reconhecem o maior grau de sofisticação e potência dos sistemas de proteção locais - para dele se afastar - quando rejeita a viabilidade empírica de um gradual e progressivo aprimoramento e fortalecimento do sistema internacional rumo à proteção integral e efetiva dos direitos humanos sob a batuta dos seus oponentes históricos.

Nessa ordem de ideias, pontifica Douzinas (2009, p. 155 - 156):

\footnotetext{
${ }^{5}$ Segundo Douzinas (2009, p.131), "A lei internacional de direitos humanos administrada por governos é a melhor ilustração do caçador transformado em guarda-caça".
} 


\begin{abstract}
Tudo isso não significa que tratados e declarações de direitos humanos são desprovidos de valor. Neste momento do desenvolvimento do Direito Internacional, seu valor é principalmente simbólico. Os direitos humanos são violados dentro do Estado, da nação, da comunidade, do grupo. Do mesmo modo, a luta para mantê-los pertence aos dissidentes, às vítimas, àquelas pessoas cuja identidade é negada ou denegrida, aos grupos de oposição, a todos aqueles que são alvos de repressão e dominação. Somente pessoas em ação de base e local podem aprimorar os direitos humanos; pessoas de fora, incluindo organizações por direitos humanos, podem ajudar ao apoiá-los.
\end{abstract}

Retomando o ponto fundamental, considere-se que a máxima preservação da soberania do Estado, projeção sobre o ente artificial da soberana liberdade individual do estado de natureza do jusnaturalismo moderno, é o imperativo norteador da instituição do Sistema das Nações Unidas e do subsistema de proteção internacional dos direitos humanos, sendo consequentemente a fonte primária das virtudes e vícios verificáveis como associadas à conformação sistemática.

Em obra fortemente influenciada pelo ideal liberal do Estado de Direito Global, consoante se infere a partir do seu título "DIREITOS HUMANOS e o Direito Constitucional Internacional", Flávia Piovesan (2009, p. 159 e ss) ao discorrer sobre a "estrutura normativa do sistema global de proteção internacional dos direitos humanos" e do seu principal instrumento, o mecanismo de monitoramento e controle (international accountability) fruto do processo de juridicização da DUDH de 1948, cuida logo em seguida de ressalvar os limites do direito emergente desde o fim da Segunda Guerra Mundial.

Assim, o Direito Internacional dos Direitos Humanos - DIDH caracteriza-se essencialmente por ser subsidiário e suplementar vez que os deveres de respeito, proteção e promoção dos direitos humanos são encargos assumidos individual e primariamente pelo Estado, cabendo à Comunidade Internacional apenas a eventual responsabilidade subsidiária e/ou suplementar na hipótese do reconhecimento institucional de inação ou insuficiência da atuação estatal ensejadora de afronta a direito ou liberdade fundamental integrante do catálogo constitutivo do mínimo denominador comum da eticidade universal.

Saliente-se, em desdobramento, que do caráter subsidiário e suplementar do DIDH e do seu correspondente sistema de proteção emerge a exigência de esgotamento das possibilidades instrumentais disponibilizadas pelo ordenamento 
jurídico local para a garantia de direitos humanos como requisito, geralmente necessário e inafastável, para a admissibilidade preliminar da apreciação de casos de supostas violações de tais direitos perante os organismos internacionais de proteção globais ou regionais.

As considerações até aqui consignadas não pretendem em nenhuma hipótese rejeitar ou escamotear os aportes institucionais, doutrinários e jurisprudenciais associados à temática dos direitos humanos, nem as contribuições teóricas ou práticas de movimentos e entidades que reivindicam direitos humanos em escala local, regional ou planetária. O que se pretende é somente contribuir para o desvelamento do teor ideológico de certas premissas dogmáticas bastante influentes em tema de direitos humanos de modo a proporcionar as condições imprescindíveis à percepção de novos horizontes teóricos mais próximos à realidade dinâmica e suas múltiplas e contraditórias possibilidades.

Cumpre agora avançar visando compreender o contexto que impulsionou a incorporação da questão da deficiência nos campos da teoria, da práxis e da normatividade dos direitos humanos, precipuamente a incorporação ao ordenamento jurídico brasileiro da Convenção sobre os Direitos das Pessoas com Deficiência CDPD por meio do procedimento de constitucionalização das suas cláusulas, para em seguida apreciar caso paradigmático de aplicação jurisdicional no plano local da proteção jurídica especial formalmente emancipadora.

\section{AS ABORDAGENS RELATIVAS AO FENÔMENO DA DEFICIÊNCIA E A EMANCIPAÇÃO FORAL DA COLETIVIDADE HUMANA DISCRIMINADA E EXCLUÍDA}

A ignorância, a negligência, a superstição e o medo constituem fatores sociais que, ao longo da história, têm vindo a isolar as pessoas com deficiências e atrasar o seu desenvolvimento. (Parágrafo 3 da Introdução às Regras Gerais sobre Igualdade de oportunidades para pessoas portadoras de deficiência, proclamada pela Organização das Nações Unidas - ONU, no ano de 1993). 
A Convenção sobre os Direitos das Pessoas com Deficiência-CDPD e seu Protocolo Facultativo entraram em vigor no sistema das nações unidas aos 03 de maio de 2008 com o deliberado fim de conferir à coletividade humana com deficiência uma proteção especial aliada àquela reconhecida a todos e a cada um dos membros da família humana pela Declaração Universal de 1948 e dos Pactos Internacionais de 1966.

O primeiro tratado internacional versando sobre direitos humanos do século XXI pretende levar a efeito a promoção, a proteção e a garantia do pleno e equitativo exercício de todos os direitos humanos, assim como promover o respeito pela dignidade inerente aos seres humanos que constituem a minoria historicamente discriminada, apartada e oprimida nas múltiplas dimensões da vida humana associada. Cuida-se, assim, da mais recente expressão do processo de especificação identificado por Bobbio (2004, p. 58), referido no tópico anterior.

O Estado brasileiro participou ativamente de todo o processo deflagrado pela Organização das Nações Unidas - ONU que culminou com a incorporação do novo tratado ao Sistema Internacional de Proteção dos Direitos Humanos (LOPES, 2014). Destaque-se, no que diz respeito aos esforços empreendidos no contexto interno, que a ratificação da CDPD e seu Protocolo Facultativo por intermédio do Decreto Legislativo no 186/08, com a observância do procedimento encartado no $\S^{\circ}$ do art. 5을 da Constituição da República Federativa do Brasil-CRFB, implicou na incorporação do texto convencional ao ordenamento jurídico nacional com o status de Emenda Constitucional. Em outras palavras, as cláusulas previstas na CDPD são, no contexto do direito brasileiro, para todos os efeitos, normas jurídicas de estatura constitucional.

Um retrospecto histórico tendo por alvo os documentos da ONU que se dedicaram à temática da deficiência ${ }^{6}$ até 0 advento da CDPD em muito contribuiria para a percepção/compreensão dos embates teóricos que as questões associadas ao tema despertaram, e ainda despertam, na literatura especializada. Contudo, a magnitude da empresa extrapolaria os estreitos limites do estudo que ora se desenvolve.

${ }^{6}$ Especialmente: a Declaração dos Direitos das Pessoas Deficientes (1975); o Programa de Ação Mundial para a Pessoas Deficientes (1982) e as Normas para equiparação de oportunidades para pessoas com deficiência (1993). 
Em sendo assim, buscando-se exclusivamente delinear um quadro geral, assente-se inicialmente a identificação de três modelos de explicação da deficiência (CARVALHO; ROCHA; SILVA, 2006), afirmando-se desde já que não se sucedem historicamente, mas sim coexistem, de modo que se pode falar em uma maior ou menor influência de um ou de outro arquétipo em determinada quadra histórica de uma específica formação social.

Averbada a advertência quanto ao equívoco de uma evolução histórica linear, o que não significa negar uma precedência histórica na formulação dos modelos, acentua-se que a deficiência foi e é compreendida como um fenômeno metafísico, biomédico ou sociológico.

A explicação metafísica, ou mística, percebe a deficiência como resultante da ação de forças sobrenaturais, obra divina ou demoníaca diante da qual o ser humano pouco ou nada pode fazer além de submeter-se à vontade do todo poderoso ou implorar/negociar o resgate da benção ou do castigo, conforme o caso (CARVALHO; ROCHA; SILVA, 2006; MAZZOTTA, 2011).

A compreensão biomédica entende a deficiência como doença, patologia ou anormalidade que precisa ser curada ou minimizada. Sob tal perspectiva, a deficiência é um problema do indivíduo que, submetido às consequências próprias da sua condição patológica, não dispõe das aptidões exigidas pela vida em sociedade sendo, em corolário, excluído do meio social (DINIZ; MEDEIROS; SQUINCA, 2007).

Por seu turno, a explicação sociológica do chamado modelo social procura deslocar a questão da deficiência do âmbito individual para o político, invertendo a lógica do modelo médico. Assim, a deficiência é fenômeno que resulta não de causas naturais, mas de causas sociais como a pobreza, a violência, a poluição e o envelhecimento7. Nessa linha de raciocínio, não é o impedimento físico, mental, intelectual ou sensorial diagnosticado na conformação do ser humano que acarreta a exclusão social da pessoa com deficiência. Ao revés, é a configuração uniformizadora dos espaços sociais em suas múltiplas dimensões que não permitem

${ }^{7}$ Segundo Colin Barners, sociólogo de inspiração marxista e um dos fundadores do modelo social da deficiência no Reino Unido, ao acentuar que os impedimentos são causados socialmente, em entrevista à Diniz (2013). 
a participação de uma pessoa com deficiência em igualdade de condições com as demais pessoas (DINIZ, 2007; PIOVESAN, 2009).

Em tal contexto, a inclusão social das pessoas com deficiência pressupõe a superação da cultura justificadora da discriminação e da opressão dos que compõem a minoria humana, bem como a completa transformação material do meio social, afastando-se assim, com as mudanças de ordem cultural e material, as barreiras da intolerância e da apartação da coletividade que exprime uma das facetas da diversidade humana: a deficiência.

As proposições iniciais do modelo social surgiram particularmente no Reino Unido e nos Estados Unidos da América, a partir de 1970, sob o influxo do pensamento marxista. Desde então, o modelo incorporou aos seus horizontes teóricos contribuições das abordagens feministas, culturalistas e pós-modernistas (DINIZ, 2007).

Destaque-se aqui as contribuições das correntes feministas à compreensão da deficiência que enfatizam as questões das discriminações múltiplas e do envelhecimento, o cuidado como imperativo ético e a afirmação do paradigma da interdependência humana, postulados que ampliaram a compreensão do modelo social da deficiência e, por outro lado, precipuamente os dois últimos, instauram conflito aberto em face das premissas da autonomia e da independência incondicionadas do individualismo liberal.

Agregue-se que o modelo de explicação biomédico da deficiência igualmente ganhou aprimoramento e sofisticações. A Classificação Internacional de Funcionalidade, Incapacidade e Saúde - CIF, encampada pela Organização Mundial da Saúde - OMS no ano de 2001, ao mesmo tempo em que põe fim à relação de sinonímia entre deficiências e doenças, estas últimas encartadas na Classificação Estatística Internacional das Doenças e Problemas Relacionados com a Saúde- CID 10, busca uma solução de compromisso entre os arquétipos social e biomédico ao propor um modelo biopsicossocial para a avaliação das deficiências, o que foi considerado ao mesmo tempo um sinal da ascensão do modelo social e a perpetuação do modelo biomédico, ainda que temperado e aberto aos aportes de outras áreas do conhecimento, impondo-se assim a compreensão multidisciplinar do 
termo deficiência (DINIZ; MEDEIROS; SQUINCA, 2007; DINIZ; BARBOSA; SANTOS, 2009).

Tal é o pano de fundo diante do qual se pode captar o significado da expressão "pessoas com deficiência", assim definido no art. 1 da CDPD como aquelas que tem impedimentos de longo prazo de natureza física, mental, intelectual ou sensorial, os quais, em interação com diversas barreiras, podem obstruir sua participação plena e efetiva na sociedade em igualdade de condições com as demais pessoas.

Em uma aproximação inicial, cumpre considerar duas observações assentadas na alínea "e" do preâmbulo do texto convencional. A primeira delas assevera que $\mathrm{o}$ conceito de deficiência se encontra envolto em um processo evolutivo, alertando o intérprete da convenção para a necessidade de buscar seu significado à luz do texto e do contexto do novo tratado, de modo a afastar equívocos que resultariam da consideração de sentidos associados ao termo no passado, dentre eles o prejudicial engano na identificação dos sujeitos de direitos destinatários da proteção especial (SEGALLA; ARAUJO, 2012; LOPES, 2014).

A segunda acentua que a deficiência resulta da interação entre pessoas com impedimentos e as barreiras devidas às atitudes e ao ambiente que impedem a plena e efetiva participação dessas pessoas na sociedade em igualdade de oportunidades com as demais pessoas. A asserção preambular, na esteira da anterior, pretende alertar o hermeneuta sobre o caráter complexo e multidimensional do fenômeno da deficiência que já não mais se circunscreve nas estreitas fronteiras do conhecimento das ciências biomédicas (DINIZ; MEDEIROS; SQUINCA, 2007).

Assim, o texto convencional constitucionalizado inova o ordenamento jurídico nacional que anteriormente sempre se pautou por critérios biomédicos para a avaliação e identificação das pessoas portadoras de deficiência, na terminologia pretérita, mas ainda não de todo superada na linguagem institucional assim como naquela veiculada difusamente no meio social.

Em corolário, a definição constitucional da expressão "pessoas com deficiência", inspirada em uma compreensão biopsicossocial da deficiência, é conceituação complexa mais sofisticada e mais abrangente que as definições anteriores, incide e repercute em todos os ramos do direito positivo nacional, 
constituindo-se em definição chave para a identificação dos titulares da proteção especial institucionalizada no sistema jurídico local e no sistema internacional de proteção dos direitos humanos.

$\mathrm{Na}$ conformação dessa proteção especial faz-se mister realçar, tanto pelo impacto da inovação quanto em razão do objeto deste artigo, que o microssistema convencional rompe o silêncio sinistro dos documentos anteriores emanados do Sistema das Nações Unidas sobre os direitos civis e políticos, igualmente ausentes da maioria dos ordenamentos jurídicos locais ${ }^{8}$ com relação a expressiva parcela do contingente social com deficiência (DHANDA, 2008).

Em corolário, a impactante guinada normativa que instituiu simbióticas conexões entre as premissas do modelo social de explicação da deficiência e o arcabouço normativo do Direito Internacional dos Direitos Humanos e, no caso brasileiro, todo o sistema jurídico nacional, deve ser aqui apreciada a partir de um esforço hermenêutico que pretende apontar suas diretrizes estruturantes, especialmente quanto ao novo regime dos direitos civis.

A principiologia convencional constitucionalizada compreende: o respeito pela dignidade inerente, a autonomia e a independência das pessoas; o princípio da não-discriminação; os princípios da participação e da inclusão social; o respeito pela diferença e pela aceitação das pessoas com deficiência como parte da diversidade humana; a igualdade de oportunidades e de gênero; o princípio da acessibilidade; e ainda, o respeito pelo desenvolvimento das capacidades das crianças com deficiência e ao direito de preservação de suas identidades (CDPD, art. 3, "a" a "h").

Alerte-se de plano que o princípio da não-discriminação investe contra determinada espécie de discriminação, a denominada discriminação negativa. Tal modalidade discriminatória se expressa por meio de qualquer diferenciação, exclusão ou restrição baseada em deficiência, com o propósito ou o efeito de dificultar ou impossibilitar o reconhecimento, o desfrute ou o exercício, em igualdade de oportunidades com as demais pessoas, de todos os direitos humanos e

\footnotetext{
${ }^{8}$ Assim, em regra, no que se refere às pessoas com deficiência, a normatização especializada dos direitos sociais precedeu o reconhecimento formal dos direitos individuais, circunstância que pode justificar o enfrentamento do tema da aparente contestação empírica da teoria geracional.
} 
liberdades fundamentais nos âmbitos político, econômico, social, cultural, civil ou qualquer outro, especialmente a recusa de adaptação razoável ${ }^{9}$ (CDPD, art. 2).

Diversa é a situação quando se verifica a ocorrência da discriminação positiva, que visa concretizar o princípio da igualdade de oportunidades. No caso, a distinção levada a efeito tendo a deficiência por parâmetro justifica a adoção de medidas direcionadas à compensação de desigualdades historicamente consolidadas, a aceleração ou o alcance da efetiva igualdade de oportunidades (isonomia substancial) em favor das pessoas com deficiência (MADRUGA, 2013).

Tal espécie de diferenciação costuma receber múltiplas designações: ação afirmativa, política compensatória, política de inclusão, política de cotas, dentre outras expressões similares. Assim, é possível inferir que a disciplina normativa do emprego da condição da deficiência como critério diferenciador é contraditória somente na aparência.

Com efeito, uma análise mais acurada permite assentar que a vedação ao uso do parâmetro, princípio da não-discriminação, assim como a chancela do seu emprego, pelo princípio da igualdade de oportunidades, estão teleologicamente associadas à efetivação dos direitos das pessoas com deficiência, ainda que sejam inversas as estratégias articuladas para o alcance do fim. Diga-se ainda, em consequência, que a ponderação dos sobreditos princípios reveste-se do status de condição necessária à implementação da meta convencional da inclusão plena da coletividade com deficiência.

O propósito de promover, proteger e assegurar o exercício pleno e equitativo dos direitos econômicos, sociais e culturais ${ }^{10}$ por todas as pessoas com deficiência, afastadas em qualquer hipótese ou circunstância as discriminações negativas baseadas em deficiência, é obrigação primária do Estado brasileiro submetida ao regime de implementação progressiva de modo que as medidas estatais devem ser

\footnotetext{
${ }^{9}$ A expressão "adaptação razoável" (reasonable accommodation) é assim definida nos termos do art. 2, do texto convencional: "[...] significa as modificações e os ajustes necessários e adequados que não acarretem ônus desproporcional ou indevido, quando requeridos em cada caso, a fim de assegurar que pessoas com deficiência possam gozar ou exercer, em igualdade de oportunidades com as demais pessoas, todos os direitos humanos e liberdades fundamentais."

10 No que se refere aos direitos econômicos, sociais e culturais o elenco convencional compreende os direitos: à educação (CDPD, art. 24); à saúde (CDPD, art. 25); à habilitação e reabilitação (CDPD, art. 26); ao trabalho e ao emprego (CDPD, art. 27); a padrão de vida e proteção social adequados (CDPD, art. 28), e à participação na vida cultural e em recreação, lazer e esporte (CDPD, art. 30).
} 
proporcionais aos recursos disponíveis (CDPD, arts. 1 e 4, incisos "1" e "2"). Assim, no que diz respeito especificamente ao regime de garantia dos direitos ESC, a tutela instituída pela Convenção de New York não foi além do sistema jurídico de proteção geral adotado pelo Pacto Internacional sobre os Direitos Econômicos, Sociais e Culturais de $1966^{11}$.

A diretriz da igualdade formal ou perante a lei, conforme o art. 12 da CDPD, estabelece que, na condição de integrantes da espécie humana, as pessoas com deficiência são sujeitos de direitos, dotadas de capacidade legal em todos os aspectos da vida podendo contar, quando necessário, observadas as cautelas legais e o controle judicial, do apoio de terceiros no exercício da capacidade civil, especialmente no que diz respeito aos direitos de natureza patrimonial.

A garantia de acesso à justiça ${ }^{12}$ às pessoas com deficiência, projeção singular do princípio da acessibilidade, compreende a efetiva participação direta e indireta, inclusive como testemunha, em todos os processos e procedimentos jurídicos mediante a adoção de medidas adequadas relacionadas a adaptações processuais e capacitação dos recursos humanos do sistema de justiça e segurança pública (CDPD, art. 13).

A diretriz reitora da órbita familiar encontra-se inserta no art. 23 da CDPD sob a epígrafe "Respeito pelo lar e pela família", inspirada nas contemporâneas proposições atinentes à personalização do direito de família, do afeto como

11 No entender de Douzinas (2009, p.136) com os Pactos de 1966 "os direitos humanos, acompanhando as prioridades ocidentais, foram hierarquizados", de modo que os direitos civis e políticos, os titulares supostamente permanentes e universais do plantel jurídico liberal, gozam de primazia quando se confrontam com os direitos econômicos, sociais e culturais. A evidência da predileção de matiz ideológica é, precisamente, os distintos regimes de implementação: imediata, para os CP, e progressiva, para os ESC.

${ }^{12}$ Araújo e Saldanha (2017) assentam que a virtualização dos procedimentos judiciais no Brasil vem sendo levada a cabo em aberto descompasso com as diretrizes normativas da CDPD e do Estatuto da Pessoa com Deficiência (Lei no 13.146/15), especificamente as destinadas à garantia às pessoas com deficiência do acesso pleno e autônomo à justiça, à informação e à comunicação, assim como a toda e qualquer dimensão da vida social. Consoante os autores, o Processo Judicial Eletrônico - Pje, principal ferramenta do projeto de jurisdição virtual em fase de execução, e que já absorveu elevadíssimas inversões de recursos públicos, foi desenvolvida de modo que não permite o seu manuseio direto por pessoa com deficiência visual que, por isso, necessitará do auxílio de terceiros, situação que restou conhecida com a divulgação do caso Deborah Prates. A advogada buscou o Conselho Nacional de Justiça - CNJ pleiteando, sem sucesso, provimento administrativo que Ihe assegurasse a continuidade do exercício de sua profissão com autonomia, em razão da implantação do inacessível sistema PJe. A questão veio a ser parcial e provisoriamente equacionada com a concessão de liminar em 31/01/14, no MS no 32.751-DF, em tramitação no Supremo Tribunal Federal, que assegurou à advogada carioca protocolar suas petições e documentos em papel enquanto não fossem suprimidas as barreiras na arquitetura do sistema eletrônico. 
elemento central e conformador do núcleo familiar e da primazia dos valores da dignidade humana, da solidariedade e da igualdade no contexto das relações familiares (FERRAZ; LEITE, 2014).

A normatividade convencional institui mudanças de grande monta na tradicional disciplina civilista que olvidava os dogmas da autonomia, da liberdade e da independência individuais com relação a significativa parte do contingente com deficiência, justificando no plano normativo a opressão familiar e social envolta na cultura discriminatória excludente das pessoas com deficiência e que, de regra, permanece escondida pela máscara da proteção daqueles que são efetivamente por ela estigmatizados e oprimidos.

Assim, resta estabelecido como pressuposto inarredável à viabilização das relações inclusivas na esfera familiar o encargo estatal de implementação de medidas apropriadas para eliminar a discriminação contra pessoas com deficiência em todos os aspectos relativos a casamento, família, paternidade e relacionamentos.

Em desdobramento, o novo regime é estruturado com a fixação das seguintes diretrizes: direito de contrair matrimônio e constituir família; direitos reprodutivos e ao planejamento familiar; direitos e responsabilidade relativos a guarda, tutela e adoção de crianças; direitos das crianças com deficiência ao convívio familiar; proteção ao exercício do poder familiar, que somente poderá ser suspenso ou extinto por provimento jurisdicional lastreado no superior interesse da criança, não podendo a condição de deficiência de quaisquer dos integrantes do núcleo familiar ser valorada negativamente para justificar qualquer limitação do direito protegido; por fim, o dever estatal de assegurar que os cuidados dispensados à criança com deficiência sejam assumidos preferencialmente por sua família natural ou extensa, sendo excepcional o recurso a soluções comunitárias.

É preciso ainda destacar que a compreensão do sentido e do alcance das diretrizes até aqui explicitadas exige a consideração das garantias associadas à prevenção contra a exploração, a violência e o abuso (CDPD, art. 16), à proteção da integridade da pessoa (CDPD, art. 17), à vida independente e inclusão na comunidade (CDPD, art. 19), à liberdade de expressão e de opinião e acesso à informação (CDPD, art. 21), ao respeito à privacidade (CDPD, art. 22) e à 
participação na vida política e pública (CDPD, art. 29), apenas referenciadas nesta oportunidade.

Em corolário, a hermenêutica do texto convencional constitucionalizado possibilita formular inferência que estabeleça a emancipação ${ }^{13}$ formal das pessoas com deficiência como o princípio mais geral a partir do qual se projeta e constitui sistematicamente o modelo da inclusão social da parcela humana com deficiência, que identifica as modificações estruturais do ambiente e da cultura como requisitos à universalização dos direitos em prol da minoria historicamente discriminada, excluída e oprimida.

Assente-se ainda que os textos da Convenção e do seu Protocolo Facultativo cometem primariamente a cada um dos Estados-parte os encargos imprescindíveis à efetivação dos direitos constitutivos do programa especial instituído em favor das pessoas com deficiência, reafirmando no particular os traços da subsidiariedade e da suplementariedade das obrigações do sistema internacional de proteção dos direitos humanos, impondo-se em consectário o esgotamento prévio dos mecanismos instrumentais previstos na ordem jurídica local como condição prévia e inarredável ao acesso ao sistema internacional, conforme já acentuado no tópico antecedente.

Institucionalizada na dimensão normativa a proposição emancipatória em todas as instâncias da vida humana associada em favor da coletividade com deficiência, é preciso submeter à prova, no contexto local, a viabilidade empírica da tutela jurídica postulada coletivamente relativa à controvérsia de natureza cível, precisamente a seara mais profundamente atingida pelo imperativo emancipador e, por isso mesmo, um dos seus principais desafios.

${ }^{13}$ Conforme esclarece Douzinas (2009, p. 23 e 104), o ideal emancipatório da modernidade significa o progressivo abandono dos mitos e dos preconceitos em favor da prevalência da razão em todas as áreas da vida. 


\section{UM CASO REPRESENTATIVO DOS DESAFIOS VERIFICADOS NO PROCESSO DE EFETIVAÇÃO DOS DIREITOS DAS PESSOAS COM DEFICIÊNCIA NA REALIDADE NACIONAL}

Tendo por foco o objeto do presente artigo, buscou-se no repositório eletrônico oficial da jurisprudência do Superior Tribunal de Justiça - STJ a identificação de casos solucionados com fundamento na Convenção sobre os Direitos das Pessoas com Deficiência - CDPD, destacando do acervo aqueles nos quais a controvérsia fosse originária de relação jurídica da ordem privada, o que resultou na seleção da demanda coletiva civil consubstanciada no Resp. no 1.315.822-RJ.

Consoante se extrai da análise do inteiro teor do acórdão, em sua origem o caso foi submetido à apreciação do Poder Judiciário carioca em face do ajuizamento de ação civil pública pela Associação Fluminense de Amparo aos Cegos - AFAC contra o Banco do Brasil S/A, pretendendo a organização não-governamental provimento jurisdicional que impusesse à instituição financeira demandada a adoção de medidas destinadas ao adequado atendimento das pessoas com deficiência visual que com ela mantivessem ou viessem a estabelecer vinculação de natureza contratual, precipuamente a disponibilização de documentos em braille e a instituição de código de conduta a ser observado por seus empregados quando do relacionamento com clientes com deficiência visual.

Pleiteava ainda a entidade da sociedade civil demandante a condenação da instituição financeira demandada ao ressarcimento de danos morais coletivos, a imposição de multa diária na hipótese do descumprimento das obrigações impostas na sentença e, por fim, a projeção erga omnes dos efeitos do decisum em todo o território nacional.

O julgamento de primeiro grau impôs à instituição financeira confeccionar em braille os contratos de adesão e todos os demais documentos fundamentais para a relação de consumo, a enviar os extratos mensais consolidados por meio de impressos em linguagem braille para os clientes com deficiência visual e, ainda, a desenvolver cartilha para seus empregados contendo normas de conduta para o atendimento aos deficientes visuais, fixando prazo de sessenta (60) dias para o 
cumprimento das obrigações impostas na sentença, sob pena de multa diária no valor de $\mathrm{R} \$ 50.000$ (cinquenta mil reais) em caso de descumprimento. Por fim, restou arbitrado na sentença o montante de $R \$ 500.000$ (quinhentos mil reais) a título de indenização pelos danos morais coletivos causados, a ser recolhido em favor do Fundo de Defesa dos Direitos Difusos.

Registre-se que o Tribunal de Justiça do Estado do Rio de Janeiro - TJRJ, quando do julgamento dos recursos interpostos pelas partes, manteve inalterados os termos da condenação imposta à demandada pelo juiz sentenciante, provendo parcialmente a apelação da parte autora tão somente para atribuir efeitos erga omnes ao julgado, com abrangência a todo o território nacional, disposição não encampada pelo julgador de primeira instância.

O desfecho do encadeamento fático até aqui descrito se dá com a interposição do Recurso Especial pela instituição financeira inconformada com o acórdão do TJRJ, pretendendo anular o processo ab initio, com a invocação de questões preliminares que não interessam ao objeto deste estudo, ou ao menos minimizar os efeitos da condenação sofrida com a consideração das razões de mérito que podem ser assim sintetizadas: as normas legais que supostamente justificariam a imposição das obrigações fixadas na sentença e confirmadas pelo Tribunal ou não disciplinam tais encargos ou careceriam de regulamentação; a condenação por danos morais coletivos seria descabida vez que o reconhecimento da ocorrência do dano moral não prescinde do exame individual das supostas dor e angústia sofridas pelas vítimas; os valores correspondentes ao ressarcimento dos danos morais coletivos e à multa diária afrontariam os princípios da razoabilidade e da proporcionalidade, e, finalmente, os efeitos da sentença, nos termos do art. 16 da Lei no 7347/85 (Lei da Ação Civil Pública-LACP), deveriam ser restringidos aos limites territoriais do órgão jurisdicional prolator da decisão.

O Recurso Especial no 1.315.822-RJ veio a ser julgado em 24 março de 2015 pela Terceira Turma do STJ que, à unanimidade, acompanhou o voto do Relator Ministro Marco Aurélio Bellizze, dando parcial provimento ao recurso, a partir da articulação das premissas consubstanciadas no voto condutor, conforme se passa a reconstruir por meio de um esforço em direção à síntese. 
As obrigações impostas jurisdicionalmente à instituição financeira recorrente encontram-se lastreadas em normatividade de hierarquia legal e constitucional. A obrigação geral de utilização do método braille no Brasil remonta à entrada em vigor da Lei $n=4.169 / 62$, que tornou oficial o emprego do método braille para a escrita e a leitura do cego. No que se refere especificamente ao uso da linguagem braille nas relações contratuais bancárias mantidas entre a instituição financeira e seus clientes com deficiência visual, bem como quanto ao atendimento prioritário e diferenciado aos consumidores com deficiência, o que exige a capacitação dos recursos humanos da recorrente, conjugando-se tais providências para viabilizar acesso integral e direto às informações essenciais às transações financeiras à clientela com deficiência visual, em condições de isonomia com as demais pessoas, são encargos que podem ser extraídos da hermenêutica sistemática não só do microssistema legal de proteção especial dos direitos e interesses das pessoas com deficiência como também do microssistema especialmente voltado à proteção dos consumidores ${ }^{14}$.

As determinações judiciais impostas à recorrente são chanceladas pelo princípio da dignidade da pessoa humana, fundante e norteador do Estado Democrático de Direito, porquanto foram estabelecidas com o preciso fim de concretizar em favor das pessoas com deficiência visual, aspectos salientes e conformadores da dignidade humana, tais como o tratamento materialmente isonômico, a liberdade de fazer suas próprias escolhas, a viabilização efetiva da autonomia individual por meio da real e direta acessibilidade à comunicação e à informação que por sua vez, em corolário, resguarda a intimidade individual.

A Convenção sobre os Direitos das Pessoas com Deficiência - CDPD, incorporada ao direito nacional com o valor equivalente ao de uma emenda constitucional, por instituir direitos e garantias fundamentais ao indivíduo, tem incidência concreta e imediata, consoante se pode inferir dos enunciados encartados nos $\S \S 1^{\circ}$ e $3^{\circ}$ do art. $5^{\circ}$ da CRFB/88.

\footnotetext{
${ }^{14}$ Acentue-se que tal raciocínio parece ter implícita na sua construção a premissa técnica da interpretação da ordem infraconstitucional a partir dos valores que o intérprete reconhece como prestigiados na constelação axiológica da ordem constitucional, uma das proposições sustentadas pelo neoconstitucionalismo (OLIVEIRA NETO, 2015).
} 
Uma incursão pelo texto convencional considerando o seu propósito de efetivação do exercício de todos os direitos humanos pelas pessoas com deficiência em igualdade de oportunidades com as demais pessoas (art. 1), as definições de comunicação, discriminação por motivo de deficiência e adaptação razoável (art. 2), seus princípios nucleares (art. 3), as obrigações assumidas pelo Estado e pela sociedade brasileira (art. 4), o sentido e o alcance da acessibilidade (art. 9), e finalmente, as simbióticas relações que agregam as garantias das liberdades de expressão e de opinião ao imperativo do acesso à informação (art. 21) $)^{15}$, levou 0 Colegiado a assentar, nos termos do voto do relator (fls. 15/6):

[...] a não utilização do método braille, durante todo o ajuste bancário levado a efeito com pessoa portadora de deficiência visual (providência, é certo, que não importa em gravame desproporcional à instituição financeira), impedindo-a de exercer, em igualdade de condições com as demais pessoas, seus direitos básicos de consumidor, a acirrar a inerente dificuldade de acesso às correlatas informações consubstancia, a um só tempo, intolerável discriminação por deficiência e inobservância da almejada "adaptação razoável". A propósito, sobre a razoabilidade da exigência legal, importante deixar assente que, segundo sustentado pelo autor e não infirmado pela parte requerida, a impressão de uma folha no método braille custaria o singelo valor de $R \$ 1,00$ - um real - de fato, verdadeiramente ínfimo diante da relevância dos direitos a que se busca preservar.

Sobre a controvérsia em torno da ocorrência de danos morais transindividuais, o acórdão se filia às correntes mais avançadas nas searas doutrinária e jurisprudencial que advogam a necessidade de superação das concepções individualistas em matéria de dano moral, sustentando a extensão da tutela jurídica em favor de coletividades sociais que podem ter sua dignidade ameaçada ou lesionada por ato que se reflete de modo indistinto sobre todos os que integram determinada classe, grupo ou minoria (hiper) vulnerável, como idosos consumidores e, in caso, pessoas com deficiência.

\footnotetext{
${ }^{15}$ Expressivo exemplar de direito híbrido, nova categoria de direitos humanos instituída pela CDPD e, em consequência, incorporada ao Direito Internacional dos Direitos Humanos-DIDH (DHANDA, 2008). Sustenta a autora que a CDPD reforça a afirmação principiológica da indivisibilidade dos direitos humanos, contribuindo para a superação da falsa dicotomia que extremam direitos individuais e sociais e seus correlatos regimes diferenciados de implementação (imediata e progressiva, respectivamente). Em arremate, assevera a jurista indiana que o processo de reconhecimento dos direitos das pessoas com deficiência determinou a criação de direitos híbridos, como o previsto no art. 21 da Convenção, que impõe ao Estado o cumprimento simultâneo de deveres positivos e negativos com vistas a concretizá-los em sua completude.
} 
Abandona-se, consequentemente, a exigência de aferição individualizada da dor e da angústia sofrida por esta ou aquela pessoa em favor da apuração da magnitude dos transtornos e abalos negativos à moral da coletividade, da intranquilidade social verificada em decorrência de fato violador de direito transindividual de ordem coletiva que deve ser igualmente sopesado para a formulação do juízo relativo a ocorrência do dano moral difuso, conforme se infere do seguinte excerto do voto condutor (fl. 22):

\begin{abstract}
Efetivamente, em que pese a concretude da obrigatoriedade de adotar o método braile nos contratos bancários estabelecidos com pessoas portadoras de deficiência - dissecada no tópico anterior do presente voto -, o banco recorrido, a pretexto de lacuna normativa, expressamente renite em cumprir com o aludido dever legal. Deixa-se, pois, de propiciar aos indivíduos portadores da referida restrição sensorial (contratantes efetivos ou potenciais), com plenitude, tratamento materialmente isonômico, liberdade de fazer suas próprias escolhas, real acessibilidade à comunicação e à informação essenciais, bem como proteção a sua intimidade. A inobservância de tais direitos, caros e inerentes a qualquer cidadão, repercutem de modo ainda mais incisivo no consciente coletivo dos indivíduos portadores de deficiência visual, bem como nos valores intrínsecos ao grupo, coletivamente considerado. Nesse contexto, sobressai, indene de dúvidas, que o proceder adotado pela instituição financeira insurgente causa substancial lesão ou ameaça de lesão ao patrimônio imaterial da coletividade de pessoas portadoras de deficiência visual, o que enseja, por conseguinte, o correspondente ressarcimento.
\end{abstract}

Entretanto, decidiu a Terceira Turma do STJ reduzir o quantum arbitrado a título de indenização pelos danos extrapatrimoniais coletivos fixados em $R \$ 500.000$ (quinhentos mil reais) no provimento jurisdicional monocrático, e confirmado pelo TJRJ, para o montante $\mathrm{R} \$ 50.000$ (cinquenta mil reais).

Acentue-se que a redefinição do novo patamar como razoável e adequado ao alcance do fim colimado e da importância anterior como exorbitante foram adotadas sem a invocação de qualquer precedente da Corte em casos similares, ou da explicitação da metodologia empregada pelo Tribunal para o arbitramento do novo valor do ressarcimento por danos morais coletivos.

Ademais, diga-se ainda que a expressiva redução necessitava ser justificada em face da magnitude dos direitos controvertidos e violados no caso, da destinação da soma da condenação ao custeio de políticas de inclusão em favor da minoria afrontada pela prática discriminatória promovida e abertamente sustentada pela 
recorrente ${ }^{16}$, mas também da inequívoca capacidade econômica da instituição financeira para arcar com os ônus resultantes da condenação, de caráter indiscutivelmente propedêutico, questões que foram explicitamente reconhecidas porém, mesmo assim, deixaram de ser enfrentadas argumentativamente na fundamentação do julgamento.

Idêntico foi o caminho trilhado pelo órgão colegiado ao decidir pela revisão do valor de $\mathrm{R} \$ 50.000$ (cinquenta mil reais) estabelecido para a multa diária em caso de inadimplemento das medidas determinadas na sentença, que findou por ser diminuída para $R \$ 1.000$ (hum mil reais). Com efeito, a significativa redução foi implementada a partir de singelas alusões aos parâmetros da razoabilidade e da proporcionalidade, aliadas à brevíssima menção acerca da finalidade coercitiva e não indenizatória do instituto das astreintes, conforme assentado à fl. 24 do voto condutor.

Tendo em conta o que de ordinário ocorre na praxe judicial brasileira, justifica-se supor que as expressivas reduções das verbas condenatórias foram adotadas enquanto estratégia prática direcionada a vencer a resistência da instituição financeira e, consequentemente, superar o conflito e viabilizar o desfrute dos direitos pela coletividade com deficiência. Contudo, impõe-se registrar o malogro da solução pragmática encampada no provimento jurisdicional em face da interposição pelo Banco do Brasil S/A de Embargos de Divergência no REsp $n^{\text {a }}$ 1.315.822-RJ, até o presente em tramitação no STJ.

Finalmente, ao analisar o último ponto controvertido do caso em apreciação, a Terceira Turma estabeleceu, com suporte em precedentes da Corte, ser inaplicável na espécie a pretendida limitação subjetiva dos efeitos da sentença nos termos do art. $16^{17}$, da Lei $n^{\mathbf{a}} 7347 / 85$ (LACP), tese sustentada pela instituição

16 A obstinação da instituição recorrente no sentido de não assumir o encargo de garantir o tratamento diferenciado aos seus clientes com deficiência visual por meio do emprego do método braile para a confecção dos documentos bancários, estribada na arcaica e individualista compreensão que imputava à pessoa com deficiência a culpa por sua exclusão da vida social, foi consignada sem qualquer vacilação nas razões recursais, fato que não deixou de ser captado e dimensionado no acórdão. Com efeito, o Ministro Relator chamou a atenção da Turma, à fl. 18, para a seguinte proposição formulada pela recorrente: "[...] no caso em foco, não há qualquer dificuldade no teor dos contratos regidos pelo apelante, sendo esta unicamente decorrente da deficiência visual dos assistidos pela apelada, sendo certo que estes devem se adaptar à sociedade, e não o inverso."

17 Dispõe 0 art. 16 da Lei no 7347/85, com a redação que Ihe foi dada pela Lei $n^{\circ}$ 9494/97: "A sentença civil fará coisa julgada erga omnes, nos limites da competência territorial do órgão prolator, 
financeira recorrente, uma vez que a incidência do sobredito dispositivo restringe-se às ações que tenham por objeto direitos individuais homogêneos.

Em consequência, no caso ora examinado os efeitos da sentença proferida no bojo de ação civil pública voltada à tutela de interesses coletivos stricto sensu não se encontram submetidos à sobredita limitação, razão pela qual o julgamento de primeiro grau repercute em relação a todos os consumidores com deficiência visual que pactuaram ou venham a ajustar vinculação de natureza contratual com o Banco do Brasil S/A, em todo o território nacional, o que se justifica por força do caráter indivisível dos direitos difusos e coletivos em sentido estrito, o que se pode extrair das considerações expostas às fls. $24 / 7$.

Em busca de um arremate conclusivo e crítico faz-se necessário sistematizar as seguintes considerações extraídas da análise do caso objeto do REsp no 1.315.822-RJ:

a) o manejo de ação civil pública por entidade representativa de segmento da coletividade social com deficiência em face de práticas discriminatórias e excludentes protagonizadas por pessoa jurídica de direito privado constitui-se em evidência empírica lastreadora da tese do caráter preponderantemente sociológico da exclusão das pessoas com deficiência das múltiplas dimensões da vida humana associada, assim como reforça a insuficiência da exclusiva declaração formal de direitos para a efetivação da inclusão social;

b) sem menosprezo ao pioneirismo do provimento jurisdicional na matéria, sua fundamentação assentada apenas em uma interpretação sistemática da regulamentação ordinária e constitucional/convencional, dissociada da consideração de dados disponíveis sobre a exclusão e opressão do contingente com deficiência na realidade brasileira, bem como dos aportes da dogmática jurídica e de outras áreas do conhecimento na temática, finda por não desvelar a diretriz emancipadora que anima o texto convencional;

c) o reconhecimento de danos morais transindividuais e a tutela coletiva de direitos, superações parciais do individualismo prevalente no meio jurídico, harmonizam-se e contribuem com o processo de especificação dos direitos 
humanos/fundamentais em favor de segmentos sociais minoritários, etapa ou feição contemporânea da tendência à universalização dos direitos teorizada por Bobbio (2004);

d) por outro lado, as limitações próprias da tutela jurisdicional, tanto as subjetivas quanto as objetivas, justificam inferência no sentido de que o adimplemento dos encargos que comprometem o Estado e a sociedade brasileira com a inclusão plena e efetiva das pessoas com deficiência nas múltiplas esferas do convívio social somente podem ser adequada e integralmente viabilizados no contexto das políticas públicas estruturadas para o alcance da meta da universalização dos direitos.

\section{CONCLUSÃO}

O projeto teórico de Bobbio (2004), de um Estado de Direito Mundial protetor dos direitos humanos, submisso às regras do jogo democrático e promotor da paz, a ser edificado em processo de gradual aprimoramento do Sistema das Nações Unidas não se concretizou até o momento e não se vislumbra no horizonte sinais de seu porvir, não obstante o modelo fascinar a muitos nos diversos quadrantes do globo.

As debilidades e inconsistências do sistema internacional de proteção dos direitos humanos derivam do conflito multilateral de interesses nada universais, bastando aqui lembrar apenas as ameaças e manobras belicistas que envolvem os Estados Unidos da América e as Coréias do Norte e do Sul cujos desdobramentos são imprevisíveis mas de extrema gravidade qualquer que seja o desfecho, final ou provisório, para a humanidade.

No que diz respeito particularmente à tutela jurídica internacional dos direitos humanos, não foi e não é possível aos representantes dos Estados o estabelecimento de cláusula que condicione a permanência na associação internacional ao integral respeito, proteção e promoção de tais direitos sem o iminente e bastante provável risco de esvaziamento institucional, ainda que a 
sanção excludente observasse integralmente as garantias próprias do due process of law.

Assim, sem desconsiderar a importância dos movimentos sociais e organizações não governamentais locais ou internacionais, das instituições, agências e da normatividade internacional associados aos direitos humanos, porém considerando precisamente a maior debilidade e menor potencial dos mecanismos de tutela jurídica atualmente constitutivos do Direito Internacional dos Direitos Humanos - DIDH quando comparados à proteção jurisdicional viabilizada por ordenamentos jurídicos locais, conclui-se com Douzinas (2009) que o âmbito local é o espaço privilegiado para a interposição das demandas concretizadoras de direitos humanos.

No contexto nacional, a opção se justifica mais ainda no que se refere aos direitos das pessoas com deficiência em razão da incorporação ao texto constitucional brasileiro das cláusulas da Convenção Internacional sobre os Direitos das Pessoas com Deficiência, daí decorrendo que as pretensões de materialização referem-se a direitos de estatura simultaneamente constitucional e convencional de modo que a necessidade de recurso ao DIDH e ao seu sistema protetor será sempre de caráter subsidiário e, portanto, adequado aos limites da sistemática internacional.

O imperativo emancipatório da coletividade com deficiência levado a efeito nas searas do DIDH e do ordenamento jurídico nacional, sob o influxo das proposições do modelo biopsicossocial de compreensão da deficiência e seu correspondente protótipo de tratamento includente, pressupõe a transformação material e a mudança cultural como condições imprescindíveis para sua efetivação.

A grandiosidade e complexidade das demandas transformadoras certamente extrapolam as fronteiras das práxis jurídicas que, por sinal, em certa medida ainda não assimilaram até o momento todas as repercussões e efeitos decorrentes da mudança paradigmática que exige, para além de provimentos jurisdicionais pontuais, políticas públicas destinadas à universalização de direitos civis, políticos, econômicos, sociais e culturais.

Os embates já em curso, deflagrados individual ou coletivamente, na esfera jurídica e/ou na esfera pública, reivindicando a materialização da cidadania, parecem apontar a multiplicação e a radicalização como tendências que não podem ser 
desconsideradas na arena política, particularmente em face das exigências atinentes ao redirecionamento e à formulação e implementação de políticas públicas com a direta participação da minoria interessada.

Sob tal foco, a emancipação formal do contingente com deficiência exsurge enquanto um dos aspectos, o jurídico, relevante mas limitado, que se entrelaça aos aspectos político, econômico, social, cultural e histórico que conformam a multifacética vida humana associada.

Assenta-se que a análise do julgamento pelo Superior Tribunal de Justiça do REsp. no 1.315.822-RJ, evidencia a contribuição da tutela jurisdicional no processo de efetiva implementação dos direitos titularizados por pessoas com deficiência ao assegurar, no caso singular, à coletividade com deficiência visual contratualmente vinculada à instituição financeira os direitos de acesso pleno e direto, em igualdade de condições com as demais pessoas, de toda a documentação bancária por meio de sua conversão em linguagem braile, ao atendimento prioritário e diferenciado e, ainda, à indenização por danos morais transindividuais.

Por fim, porém de expressivo relevo, os parâmetros da razoabilidade e da proporcionalidade ingressam na temática dos direitos das pessoas com deficiência por força de referências insertas no texto convencional constitucionalizado - arts. 2 (adaptação razoável) e 4, inciso "2" (proporcionalidade entre recursos e políticas) bem como foram empregados na solução da questão jurídica esquadrinhada no terceiro tópico deste artigo, evidenciando-se assim a necessidade de uma consideração particular, abrangente e aprofundada desses instrumentos da tecnologia jurídica por parte daqueles que reivindicam a materialização da proteção jurídica especial. Quais são os elementos que compõem as equações da razoabilidade e da proporcionalidade? O julgamento do Recurso Especial ํo 1.315.822-RJ não responde.

\section{REFERÊNCIAS}

ARAUJO, Luiz Alberto David; SALDANHA, Paloma Mendes. Processo judicial eletrônico e o Estatuto da Pessoa com Deficiência: novidades, ilegalidades e inconstitucionalidades. Revista Direitos Fundamentais \& Democracia, v. 22, n. 1, p. 80-101, jan/abr, 2017. ISSN 1982-0496. Disponível em: 
$<$ http://revistaeletronicardfd.unibrasil.com.br/index.php/rdfd/article/view/850> Acesso em: 20 set 2017.

BOBBIO, Noberto. A era dos direitos. Trad. Carlos Nelson Coutinho. Apresentação Celso Lafer. Rio de Janeiro: Elsevier, 2004.

BRASIL. Decreto no 6.949 de 25 de agosto de 2009. Promulga a Convenção Internacional sobre os Direitos das Pessoas com Deficiência e seu Protocolo Facultativo, assinados em Nova York, em 30 de março de 2007. Disponível em <http://www.planalto.gov.br/ccivil_03/_ato2007-2010/2009/decreto/d6949.htm > Acesso em: 20 ago. 2015.

Lei no 13.146, de 6 de julho de 2015. Institui a Lei Brasileira de Inclusão da pessoa com deficiência (Estatuto da Pessoa com Deficiência). Disponível em: <http://www.planalto.gov.br/ccivil_03/_Ato2015-2018/2015/Lei/L13146.htm> Acesso em: 30 ago. 2015.

STF-Supremo Tribunal de Federal. MS 32.751 (995637390.2014.1.00.0000). Rel. Min. Celso de Mello. Disponível em: $<$ http://portal.stf.jus.br/processos/detalhe.asp?incidente=4522711>. Acesso em: 08 jul 18.

. STJ-Superior Tribunal de Justiça. EREsp. 1.315.822-RJ (2012/00593220). Rel. Min. Maria Isabel Gallotti. Disponível em: $<$ https://ww2.stj.jus.br/processo/pesquisa/>. Acesso em 08 jul 18.

STJ-Superior Tribunal de Justiça. REsp. 1.315.822-RJ (2012/0059322-0). Rel. Min. Marco Aurélio Bellizze. Brasília, DF, 24 de março de 2015. Disponível em: <https://ww2.stj.jus.br/processo/revista/documento/mediado/?componente=ATC\&seq uencial $=45281207 \&$ num_registro $=201200593220 \&$ data $=20150416 \&$ tipo $=5 \&$ formato $=$ PDF>. Acesso em: 27 set 2017.

CARVALHO, Alfredo Roberto; ROCHA, Jomar Vieira da; SILVA, Vera Lucia Ruiz Rodrigues da. Pessoa com Deficiência na história: modelos de tratamento e compreensão. In: Pessoa com deficiência: aspectos teóricos e práticos. Edunioeste, 2006.

DALLARI, Dalmo de Abreu. Igualdade de direitos: conquista da humanidade. In: BERTOLDI, Márcia Rodrigues; SPOSATO, Karyna Batista (Coord.). Direitos humanos: entre a utopia e a contemporaneidade. Belo Horizonte: Fórum, 2011. P. 289-295. ISBN 978-85-7700-516-1.

DHANDA, Amita. Construindo um novo léxico dos direitos humanos: Convenção sobre os direitos das pessoas com deficiências. Sur, Rev. int. dir. Humanos, v.5, n.8, São Paulo, jun. 2008. Disponível em:< http://www.surjournal.org/conteudos>. Acesso em: 28 abr. 2014. 
DINIZ, Debora. Deficiência e políticas sociais: entrevista com Colin Barners. SER Social, Brasília, v. 15, n. 32, p. 237-251, jan/jun 2013. Disponível em: <http://periodicos.unb.br/index.php/SER_Social/article/view/9514/7088> Acesso em: 20 set 2017

Passos.

O que é deficiência. São Paulo: Brasiliense, 2007. Coleção Primeiros

; BARBOSA, Lívia; SANTOS, Wederson Rufino dos. Deficiência, direitos humanos e justiça. SUR, v. 6, n. 11, dez 2009, p. 65-77, Disponível em: <http://www.surjournal.org/conteudos/getArtigo11.php>. Acesso em: 04 maio 2014.

; MEDEIROS, Marcelo; SQUINCA, Flávia. Reflexões sobre a versão em Português da Classificação Internacional de Funcionalidade, Incapacidade e Saúde. Cadernos de Saúde Pública, Rio de Janeiro, 23(10):2507-2510, out, 2007. Disponível em: <http://www.scielo.br/scielo.php?script=sci_pdf\&pid=S0102$311 \times 2007001000025 \&$ Ing=pt $>$ Acesso em: 20 set 17

DOUZINAS, Costas. 0 fim dos direitos humanos. Tradução Luzia Araújo. São Leopoldo: Unisinos, 2009.

FEITOSA, Enoque. Bobbio e a crítica de Marx aos direitos humanos: o que e quais são os direitos humanos? Elementos para uma refutação da concepção individualista dos direitos humanos. In: TOSI, Giuseppe (Org.). Noberto Bobbio: democracia, direitos humanos, guerra e paz. Coleção Direitos Humanos. vol. 2. João Pessoa: Editora da UFPB, 2013. pp. 79-101. Disponível em: <http://www.cchla.ufpb.br/ncdh/wp-content/uploads/2015/11/Norberto-Bobbio-

Vol2.pdf> Acesso em: 20 ago 2017

FERRAZ, Carolina Valença; LEITE, Glauber Salomão. Artigo 23: Respeito pelo lar e pela família. In: DIAS, Joelson et al. (Orgs.). Novos comentários à Convenção sobre os direitos das pessoas com deficiência. Brasília: SNPD-SDH-PR, 2014. p. 152-157. <http://www.pessoacomdeficiencia.gov.br/app/sites/default/files/publicacoes/convenc ao-sdpcd-novos-comentarios.pdf>. Acesso em: 28 maio 2015.

FREITAS, Lorena. Uma análise pragmática dos direitos humanos. In: FREITAS, Lorena; FEITOSA, Enoque (Orgs.). Marxismo, realismo e direitos humanos. João Pessoa: Editora da UFPB, 2012. pp. 226-240. Disponível em: <esma.tjpb.jus.br/sites/default/files/legado/2014/06/marxismorealismo.pdf> Acesso em: 19 jan 2017

KANT, Immanuel (1724-1804). À paz perpétua. Tradução Marco Zingano. Porto Alegre-RS: L\&PM, 2016.

LOPES, Laís de Figueirêdo. Artigo 1: propósito. In: DIAS, Joelson et al. (Orgs.). Novos comentários à Convenção sobre os direitos das pessoas com deficiência. Brasília: SNPD-SDH-PR, 2014. p. 26-35. Disponível em: 
<http://www.pessoacomdeficiencia.gov.br/app/sites/default/files/publicacoes/convenc ao-sdpcd-novos-comentarios.pdf>. Acesso em: 28 maio 2015.

LOSURDO, Domenico. Marx, a tradição liberal e a construção histórica do conceito universal de homem. Disponível em: < http://www4.pucsp.br/neils/downloads/v13_14_losurdo.pdf> Acesso em: 20 ago 2017.

MADRUGA, Sidney. Pessoas com deficiência e direitos humanos: ótica da diferença e ações afirmativas. São Paulo: Saraiva, 2013.

MAZZOTTA, Marcos J. S. Educação especial no Brasil: história e políticas públicas. 6. ed. São Paulo: Cortez, 2011.

OLIVEIRA NETO, Vicente Elísio de. A fundamentação racional das decisões judiciais no Estado Democrático de Direito na teoria alexyana da argumentação jurídica: uma contribuição para o acatamento dos ditames da segurança jurídica e da justiça. In: SOBREIRA FILHO, Enoque Feitosa; BEÇAK, Rubens; COELHO, Saulo de Oliveira Pinto. (Coords.). XXIV Encontro Nacional do CONPEDI - UFS Hermenêutica Jurídica. Florianópolis: Conselho Nacional de Pesquisa e PósGraduação em Direito - CONPEDI, 2015, p. 48-65. Disponível em: <http://www.conpedi.org.br/publicacoes/c178h0tg/5911f6p7/dtkEO317cRd5MwvT.pd >. Acesso em: $1^{\circ}$ abr. 2016.

ONU - Organização das Nações Unidas. Declaração dos direitos das pessoas deficientes. Proclamada pela resolução 3447/1975 da Assembleia Geral das Nações Unidas, de 9 de dezembro de 1975. Disponível em: <http://portal.mec.gov.br/seesp/arquivos/pdf/dec_def.pdf>. Acesso em: 20 ago. 2015.

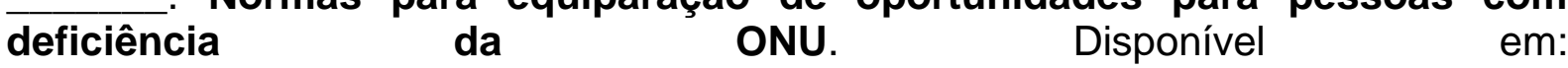
<http://styx.nied.unicamp.br/todosnos/documentos-internacionais>. Acesso em: 20 ago. 2015.

Programa de ação mundial para as pessoas deficientes - 1982. Disponível em: <http://www.direitoshumanos.usp.br/index.php> . Acesso em: 20 ago. 2015.

PIOVESAN, Flávia. Diretos humanos e o direito constitucional internacional. 10 ed. rev. e atual. São Paulo: Saraiva, 2009.

SEGALLA, Juliana Izar Sores da Fonseca; ARAÚJO, Luiz Alberto David. A utilização do novo conceito de pessoa com deficiência: uma advertência necessária. Direitos fundamentais \& Justiça, ano 6, n. 19, p. 145-159, abr/jun, 2012. Disponível em: <http://www.lexml.gov.br/urn/urn:lex:br:rede.virtual.bibliotecas:artigo.revista:2012;100 0946410">A utilização do novo conceito de pessoa com deficiência</a> Acesso em: 20 set 2017. 